\title{
PEMANFAATAN SUMBERDAYA DESA DAN OPTIMALISASI PENGGUNAAN MEDIA SOSIAL INSTAGRAM
}

\author{
Mohammad Ahyan YS ${ }^{1}$, Sholicah ${ }^{2}$, Khrisna $\mathrm{AM}^{3}$., Wanda SA ${ }^{4}$, Twovinda $\mathrm{R}^{5}$ \\ ${ }^{1}$ Dosen Program Studi Pendidikan Agama Islam, Universitas Muhammadiyah Gresik \\ 2,3,4,5Mahasiswa Prodi Manajemen, Universitas Muhammadiyah Gresik \\ Email: ahyanyusuf@umg.ac.id
}

\begin{abstract}
ABSTRAK
Secara geogrfis, Desa prijekngablak terletak diwilayah kecamatan karanggeneng Kabupaten Lamongan. Disebelah utara berbatasan dengan Desa karangrejo, disebelah timur berbatasan dengan Desa njuwet, disebelah selatan berbatasan dengan desa karangrejo. Secara umum mata pencaharian warga desa prijekngablak adalah sebagai petani baik tambak maupun petani padi. Terletak berhadapan dengan sungai Bengawan solo. Desa prijekngablak memiliki jajanan khas yaitu kerupuk ladu dan Recek (Rengginang). Namun masyarakat masih kurang pemahaman akan produksi dan pemasaran yang baik dan dapat menarik minta konsumen. Sehingga masyarakat di wilayah lain kurang mengetahui informasi tentang jajanan khas Desa Prijekngablak. Jika hal tersebut tidak dikelola dengan baik maka akan berakibat bagi perkembangan bisnis ladu dan rengginang. Hasil dari program kerja yang diadakan oleh program studi Manajemen kelompok 09 dengan membantu masyarakat dalam hal Produksi, packaging, dan Marketing agar dapat membantu masyarakat dalam keberlangsungan bisnisnya. Dalam hal produksi, Recek (Rengginang) akan dimodifikasi menjadi rengginang mini yang diberi rasa-rasa di atasnya. Lalu untuk packaging, akan diberi kemasan yang lebih menarik yaitu K-Pack dan diberi stiker. Sedangkan untuk pemasaran, rengginang akan di jual melalui media sosial agar masyarakat luas.
\end{abstract}

Kata Kunci : Produksi, packaging, Marketing 


\section{PENDAHULUAN}

\section{A. Latar Belakang}

Desa prijekngbalak adalah salah satu desa yang berada di kecamatan karanggeng kabupaten lamongan. Desa ini merupakan desa yang terkenal akan kerukunan warganya dan sumberdayaalamnya. Di desa prijek merupakan salah satu penghasil beras ketan dimana beras ketan tersebut dapat digunakan untuk pembuatan oapk ladu .

Di desa prijekngablak ini ibu ibunya mempunyai keahlian membuat recek atau yang sering disebut rengginang. Recek sendiri makanan yang hanya muncul saat perayaan sedekah bumi saja dan tidak di jual belikan.Masyarakat prijek berlatar belakang pendidikan SMA yang dimana masyarakatnya kebanyakan merantau untuk bekerja ataupun usaha diluar kota seperti : Kalimantan, Sulawesi, Bontang dan Samarinda.

\section{B. Perumusan Masalah}

Berdasarkan uraian latar belakang tersebut maka dapat dirumuskan permasalahan yang terjadi di Desa prijekngablak, diantaranya :

1) Kurangnya pemanfaatan potensi desa

2) Pengetahuan akan pemasaran opak ladu kurang berpengaruh.

\section{Tujuan Penulisan}

Tujuan penulis dalam pembuatan artikel ini adalah :

1) Mengetahui cara pembuatan rengginang

2) Mengetahui cara pemasaran melalui instagram

\section{Pembatasan Masalah}

Mengingat akan luasnya permasalahan yang terkait dalam penulisan ini, penulis hanya akan membahas tentang :

1) Bagaimana pembuatan rengginang

2) Bagaimana penjualan rengginang melalui media sosial.

3) Bagaimana meningkatkan minat masyarakat untuk memluai usaha. 


\section{METODE}

\section{A. Kerangka Penyelesaian Masalah}

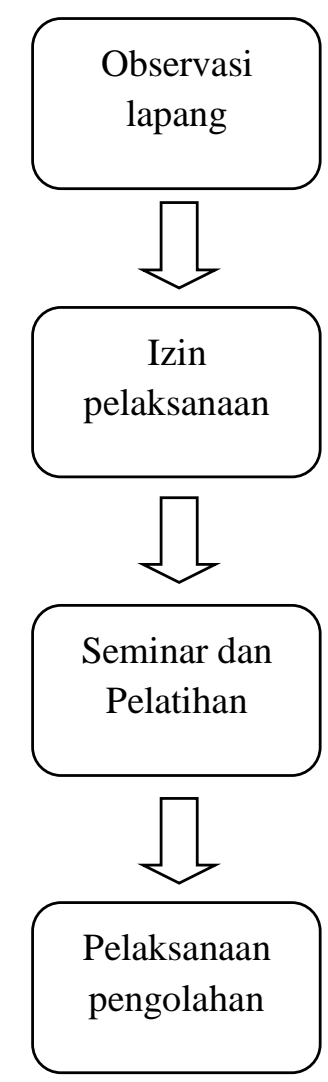

\section{Gambar 1. Flowchart Penyelesaian Masalah}

Untuk melakukan penelitian, kali ini penulis menggunakan beberapa metode yaitu sebagai berikut :

1) Metode Pengamatan

Penulis mengamati daerah - daerah sekitar rumah warga.

2) Metode Interview

Bersosialisasi dengan warga dan mengali informasi mengenai potensi desa.

\section{B. Metode Pelaksanaan}

Pelaksanaan seminar manajemen ini dilakukan dengan antusias warganya yang rela datang dan meluangkan waktunya. Kegiatan ini karna adanya pergeseran zaman yang dituntut untuk selalu mengikutinya agar tidak menjadi gagap akan teknologi. Metode pelaksanaan seperti mengumpulkan peserta pada satu tempat agar dapat berkordinasi dengan mudah dan intens dalam penyampaian materi maupun praktek 


\section{Waktu dan Tempat}

Pembuatan rengginang dan seminar dilakukan pada hari 27 Agustus 2019 yang bertempat di BalaiDesa Prijekngablak

\section{Pemecahan Masalah}

Saat ini kondisi masyarakat prijekngablak banyak yang merantau keluar jawa dan lebih memilih berjualan di luar jawa. Masyakarat prijekngablak terkenal dengan olahan ladunya yang sudah melegendaris dari zaman dahulu. Bukan hanya itu masyarakat prijek juga menghasilkan recek atau rengginang yang dimana bentuknya masih besar dan bulat.

Namun sayangnya masyarakat prijekngablak belum sepenuhnya dapat memanfaatkan potensi yang ada. Dari sinilah penulis mengambil masalah dan mencoba memecahkan masalah dengan melakukan inovasi pada olahan recek atau rengginang yang kami ubah menjadi rengginang milenial.

Renggianng mengalami inovasi dari segi raa dan bentuk. Rengginang yang semula berbentuk bulat besar menjadi bulatan kecil sekali lahap yang dimana terdapat rasa rasa pada olahannya seperti balado, avocado dan coklat.

Saat ini karna kurangnya minat masyarakat untuk menjadikan dirinya penggusaha makam kami mendatangkan pemateri agr dapat dilakukan monitoring dan motivasi.

\section{HASIL DAN PEMBAHASAN}

Program yang dilakukan oleh prodi manajemen berjalan lancar sebagaimana mestinya dengan rincian berikut :

\section{A. Tahap persiapan}

Persiapan dilakukan dengan mengidentifikasi apa saja potensi yang terdapat di Desa Prijek. Kemudian pada tahap ini juga melakukan pembuatan rengginang diposka sekaligus kami melakukan koordinasi dengan pihak terkait (Ketua PKK) untuk pelaksanaan kegiatan.

\section{B. Seminar dan pelatihan}

Pelaksanaan seminar dan pelatihan pembuatan rengginang beserta marketinya silakukan pada hari Selasa, 27 Agustus 2019 bertempat di Balai Desa Prijekngablak yang diikuti oleh kurang lebih 38 peserta dari ibu ibu maupun karangtaruna. 


\section{DedikasiMU (Journal of Community Service)}

Volume 1, Nomor 1, Desember 2019

Acara dimulai dengan Seminar dilakukan oleh narasumber serta pelaksaan program yaitu mahasiswa program manajemen. Setelah pemateri menjelaskan peserta banyak yang berantusias untuk konsultasi tentang usahanya dan bagaimana cara pembangunan pemasaran pada produknya.

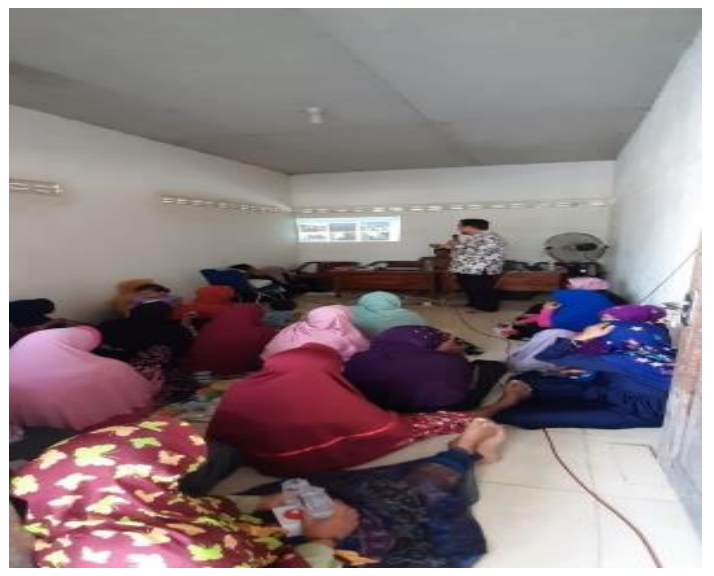

Gambar 2. Diskusi peserta dan Narasumber

\section{Pelaksanaan}

Tahap pelaksanaan ini dilakukan dengan pembuatan rengginang yang berbahan beras ketan dengan tambahan bawang putih dan garam, kemudian di campur dengan rasa-rasa seperti balado,coklat dan avocado.

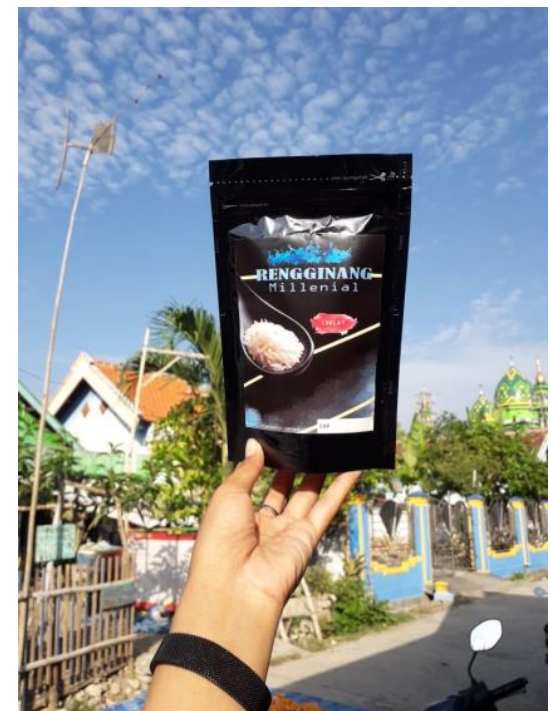

Gambar 3. Hasil olahan ikan bandeng 


\section{Pembahasan}

\section{- Proses Pembuatan Rengginang}

Produk pangan yang populer adalah berupa makanan ringan (snack food), dan salah satu jenis snack yang dikembangkan sebagai oleh-oleh adalah keripik. Produk merupakan segala sesuatu yang dapat ditawarkan produsen untuk diperhatikan, diminta, dicari, dibeli, digunakan atau dikonsumsi pasar sebagai pemenuhan kebutuhan atau keinginan pasar (Mevita dan Suprihhadi, 2013). Berdasarkan penggolongan produk menurut Kotler (2009), produk makanan termasuk keripik nenas dan rengginang ubi kayu tergolong pada produk tidak tahan lama (non durable goods) yang cepat habis dikonsumsi.Produk keripik digemari karena teksturnya yang khas, citarasanya lezat, tahan lama, praktis dibawa dan disimpan.Produk rengginang adalah produk yang berbahan dasar beras ketan yang direndam dalam air selama satu hari/8 jam kemudian ditiriskan sampai kering barulah di masak sampai matang kira kira 15 menit.selama menunggu matang kita siapkan bawangputih dan garam kemudian di ulek sampai harus barulah ketan masak diangkat dan dicampurkan dengan bawang putih kemudian siapkan loyang/tampa untuk metode penggeringanya.

Siapkan 4 loyang untung $1 / 2 \mathrm{~kg}$ beras ketan yang diolah kemudia dibentuk bulat dengan menggunakan tangan untuk pembentukan ini gunakan air untuk membasahi tangan agar tidak lengket dan mudah diatur. Setelah itu keringkan dibawah terik matahari selama 2 hari agar penggeringan maximal dan pastikan sudah benar benar kering.

Untuk penggorengan gunakan api sedang dan tunggu hingga agak kekuningan barulah di angkat dan tiriskan tunggu hingga dingin dan barulah kita campur dengan coklat cair dan bubuk balado.

Setelah itu packing menggunakan K-pack yang sudah di diberi stiker "Rengginang Millenial” kemudian.

\section{- Strategi Pemasaran}

Pemasaran adalah serangkaian kegiatan yang ditujukan untuk memperlancar pertukran barang, untuk mencapai tujuan tersebut. (Ulna,2000) Pemasaran saat ini lebih efektif dan efisien menggunakan sosial media dan merket place lainnya, karna perkembangan zaman yang pesat mendesak para pengusaha untuk berinovasi pada produknya seperti produk rengginang ini yang mana 
produk rengginang dipasarkan mengguanakan instagram yang telah terhubung dengan facebook yang biasa dinamakan instagram bisnis.

Produk rengginang sendiri disegmenkan kepada anak anak muda yang berpengahasilan meneggah ke atas.

\section{- Atribut Produk}

Pengembangan suatu produk melibatkan penentuan manfaat yang diberikan yang dinilai dari kualitas dan fitur produk. Rancangan kualitas produk merupakan kemampuan produk untuk dapat melaksanakan fungsinya meliputi daya tahan produk (Badariyansyah, 2008).

Rengginnag millenial terdiri dari 3 rasa yaitu balado, avocado, dan coklat dijual ddalam bentuk kemasan 80 gram. Daya simpanya 3-4 bulan . kemasan produk menampilkan experied dan rasa.

\section{- Pemberian Merek (Branding)}

Merek memiliki peran yang signifikan pada kemajuan perusahaan. Merek bukan sekedar nama suatu produk, tetapi sangat menentukan pada kondisi persaingan yang meningkat, karena konsumen akan mengenali merek terlebih dahulu. Bahkan dapat dikatakan bahwa merek merupakan sesuatu yang dibeli oleh konsumen (Utami, 2007).

Pemebrian merek untuk rengginang ini adalah " rengginang millenial " hal ini berawal dari segmentasi yang disasarkan kepada para millenial.

\section{- Pengemasan}

Pengemasan (packing) melibatkan kegiatan, merancang dan memberi wadah atau pembungkus suatu produk. Menurut Fakultas Ekonomi dan Bisnis Unsoed (2018). Pada umumnya kemasan yang digunakan hanyalah plastik putih yang mana tidak menarik untuk mengguah selera konsumen untuk membeli.

Kemasan rengginang millenial dikemas menggunakan K-pack (150) yang sudah dilabeli dan dipress menggunakan mesin.

\section{- Strategi Harga}

Harga adalah nilai jual yang ditetapkan oleh penjual terhadap sesuatu yang dibeli, oleh konsumen, berdasarkan keinginan untuk mendapatkan keuntungan. Pada umumnya konsumen membeli pada toko eceran yang menawarkan berbagai macam produk dengan harga yang bersaing, minimal sesuai dengan kualitas 
produk. Harga secara implisit mempunyai hubungan dengan kualitas. Kualitas produk yang baik akan dijual dengan harga tinggi sedangkan produk dengan kualitas kurang baik akan dijual dengan harga relatif rendah. Dalam realitasnya, harga mempunyai pengaruh terhadap kepuasan konsumen (Shabastian dan Samuel, 2013).

Strategi harga terdiri dari orientasi biaya, dan orientasi harga kompetitor. Penetapan harga rengginang berdasarkan biaya produksi yaitu dijual 13.000 naun untuk reseller harga menjadi 9.000/bungkus.

\section{- Strategi Promosi}

Promosi adalah bentuk komunikasi pemasaran yang berupa aktivitas pemasaran yang berusaha menyebarkan informasi, mempengaruhi atau membujuk, dan mengingatkan. Strategi promosi yang digunakan untuk pemasaran produk adalah media sosial intagram dengan menggunakan instagram bisnis yang terhubung dengan facebook.

\section{KESIMPULAN DAN SARAN}

\section{A. Kesimpulan}

- produk snack tidak menjadi hal baru bagi warga prijekngablak karna warnya sudah terbiasa membuat renggiang.

- Strategi pemsaran yang dilakukan dengan menggunakan media sosial yang banyak diminati oleh kalangan anak muda untuk saat ini.

- Strategi harga ditetapkan berdasarkan biaya produksi yang dikeluarkan.

- Rengginang dipasarkan dengan segmentasi anak muda millenial yang menggunakan media sosial instagram.

\section{B. Saran}

Produk rengginang ini memiliki potensi yang besar karna inovasi rengginang berbagai rasa belum terlalu banyak kompetitornya. Diharapkan pemerintahan desa Prijekngablak memberikan dukungan agar produk rengginang tetap bisa dilanjutkan dan dikembangkan. Pemerinta kabupaten agar di perhatikan usaha rumahan yang bergerak dibidang snack. 


\section{DAFTAR PUSTAKA}

Kotler,Philips dan Armstrong, Gary. 2008. Prinsip-Prinsip Pemasaran Jilid 1. Edisi Kedua belas. Jakarta: Erlangga

Anggrahini, Devi dan Surwati, C.H.D. 2014. Kegiatan Komunikasi Pemasaran Rown Division dalam Media Sosial (Studi Deskriptif Kualitatif Mengenai Kegiatan Komunikasi Pemasaran Rown Division di Solo melalui Media Sosial Facebook dan Twitter dalam Meningkatkan Jumlah Konsumen). http://www.jurnalkommas.com/docs/JURNAL-Devi\%20Anggrahini.pdf (diakses 17 Mei 2017).

Amanah, S. 2015. Peranan Strategi Promosi Pemasaran Terhadap Peningkatan Volume Penjualan. Jurnal LENTERA 3(1): 47-55.

Indrawijaya, S. 2012. Pengaruh Kemasan Terhadap Keputusan Konsumen dalam Pembelian Produk Industri Kecil Makanan Ringan pada Supermarket di Kota Jambi. Jurnal Manajemen Terapan dan Keuangan 1(1):33-38.

Anggreni, F. dan Praptiningsih, M. 2013. Pengelolan dan Pengembangan Usaha Distribusi makanan Ringan pada CV Timur Jaya Raya di Lombok - Nusa Tenggara Barat. Jurnal AGORA 1(2): 10 halaman. 